\title{
ACTA HYDROLOGICA
} SLOVACA

Ročník 20, č. 1, 2019, $94-101$

\section{MODELOVANIE ODNOSU SEDIMENTOV FYZIKÁLNE ZALOŽENÝM EROSION-3D MODELOM A EMPIRICKÝM MODELOM USPED V POVODÍ SVACENICKÉHO JARKU}

\author{
David Honek, Zuzana Németová, Silvia Kohnová
}

\begin{abstract}
Ciel'om príspevku je kvantifikácia odnosu sedimentov pomocou fyzikálne založeného Erosion-3D modelu a pomocou empirického modelu USPED v povodí Svacenického jarku. Analýza bola uskutočnená pre obdobie od IX. 2015 do XI. 2016, pričom vstupné údaje tvorili reálne namerané zrážkové udalosti, ktoré boli vyhodnotené ako erózne účinné v rámci zvoleného obdobia. Množstvo sedimentov určené fyzikálne založeným modelom a empirickým modelom bolo porovnané s nameranými údajmi získanými batymetriou dna v poldri, ktorý sa nachádza v povodí Svacenického jarku. Na základe výsledkov je zrejmé, že fyzikálne založený model predstavuje omnoho vhodnejší a presnejší prístup pre stanovenie množstva erodovaného materiálu v povodí, než empirický model.
\end{abstract}

KLÚČOVÉ SLOVÁ: fyzikálne založený model, modelovanie eróznych procesov, empirické modelovanie, vodná erózia, množstvo sedimentov, extrémna zrážková udalost'

\begin{abstract}
MODELLING OF SEDIMENT DELIVERY AMOUNTS BY A PHYSICALLY BASED EROSION-3D MODEL AND EMPIRICAL MODEL USPED IN THE SVACENICKY CREEK CATCHMENT. The aim of the paper is to quantify the amount of sediments using a physically based Erosion-3D model and empirical model USPED in the Svacenicky creek catchment. The analysis was carried out for the period from IX.2015 to XI.2016 with input data based on real measured rainfall events that have been determined as erosion effective within the selected period. The amount of sediments quantified by the physically based model and empirical model were compared with the measured data obtained by the bathymetry of the bottom in Svacenicky polder, which is located in the Svacenicky creek catchment. Based on the results it can be concluded that the physically based model represents more appropriate and accurate approach for determining the amount of eroded material in the catchment then an empirical one.
\end{abstract}

KEY WORDS: physically based model, modelling of erosion processes, empirical modelling, water erosion, amount of sediments, extreme rainfall event

\section{Úvod}

Intenzita a rozsah degradačných procesov pôd nadobudla v posledných rokoch podstatný nárast $\mathrm{v}$ mnohých častiach sveta (Midriak, 1993; Rawat a kol., 2011). Spomedzi jednotlivých degradačných procesov má najzávažnejšie postavenie vodná erózia pôdy, ktorá v mnohých prípadoch vedie $\mathrm{k}$ úplnému odnosu jemnozeme a tým k zániku pôdy. Doposial' jej dlhodobý a vel'koplošne pôsobiaci vplyv zapríčinil znehodnotenie vel'kej rozlohy pôdy vo viacerých krajinách (Montgomery, 2007; Terranova a kol., 2009). Z uvedeného vyplýva nielen nutnost' venovat' pozornost' jej riešeniu, ale i výskumu a zavádza- niu praktických opatrení určených na znižovanie jej intenzity. Ked’že väčšina štúdií zameraných na riešenie tejto problematiky bola uskutočňovaná pomocou empiricky založených modelov, je žiaduce použit' na hodnotenie intenzity eróznych procesov inovatívnejšie a komplexnejšie metódy a spôsoby. Jeden $\mathrm{z}$ takýchto nástrojov predstavujú fyzikálne založené modely, ktoré sa javia ako efektívna metóda kvantifikácie a hodnotenia erózie pôdy (Bhattarai a Dutta, 2007). Na druhej strane nemožno označit' empirické modely za menej hodnotný prístup posudzovania eróznych procesov, len brat' v úvahu možnost' lepšej a komplexnejšej kvantifikácie vodnej erózie pôdy. Avšak výber správneho prístupu a kvantifikácie 
eróznych procesov je silne závislý od dostupnosti kvalitných vstupných dát.

$\mathrm{V}$ posledných rokoch počet štúdií venujúcich sa problematike vodnej erózie pôdy dosiahol vysoké číslo a bolo vyvinutých mnoho metód hodnotenia intenzity vodnej erózie pôdy, avšak všeobecným problémom zostáva validácia a verifikácia použitých metodík (Garcia-Ruiz a kol., 2015). Terénne meranie erózneho zmyvu je obmedzené nielen finančnou náročnost'ou, ale tiež nedostatkom vhodných lokalít. Jedným $\mathrm{z}$ riešení, ako zistit' mieru erózie $v$ riešenom území, je meranie hrúbky sedimentov v nádržiach (García-Ruiz a kol., 2015). Tejto problematike je venovaných množstvo prác (Erskine a kol., 2002; Boix-Fayos a kol., 2008; Boyle a kol., 2011; Bussi a kol., 2013; Hlavčová a kol., 2018).

Ciel'om príspevku je nielen porovnanie výsledkov kvantifikácie objemu sedimentov vyššie opisovanými metódami, ale rovnako aj konfrontácia modelových výsledkov $\mathrm{s}$ reálne nameraným množstvom sedimentov $\mathrm{v}$ poldri na Svacenickom jarku.

\section{Materiál a metódy}

V nasledujúcej časti sú stručne popísané modely použité pre výpočet množstva sedimentov v povodí Svacenického jarku. Ide o fyzikálne založený Erosion-3D model a empirický model USPED. Ďalej nasleduje opis batymetrie dna v Svacenickom poldri slúžiaci pre porovnanie modelových výsledkov s reálne nameranými dátami.

\section{Erosion-3D model}

EROSION-3D model predstavuje fyzikálne založený model, ktorý simuluje erózne a odtokové procesy na povodiach s vel'kost'ou do $400 \mathrm{~km}^{2}$ (Schmidt a kol., 1999). Plocha povodia $v$ modeli je delená pravidelnou štvorcovou siet'ou a umožňuje identifikáciu intenzity erózie a ukladanie erodovaného materiálu vo farebnej škále.

Model umožňuje simulovat' jednu epizódu, t.j. jednu zrážkovú udalost', ale rovnako aj sekvenciu zrážkových udalostí a napodobnit' tak dlhodobú zrážkovú radu a dlhodobú simuláciu.

Ďalšou výhodou EROSION-3D modelu je výpočet založený na rastroch, ktorý umožňuje podrobnú priestorovú analýzu eróznych procesov. Model je navrhnutý vhodne pre široký záber užívatel'ov, čoho dôkazom je malý počet vstupných parametrov (Michael, 1996). Napriek tomu obt'ažnost' získania niektorých pôdnych vstupných parametrov, tak aby predstavovali dostatočne reprezentatívnu hodnotu, je vysoká. Drsnost' povrchu pôdy vstupuje do vzt'ahu pri výpočte rýchlosti povrchového odtoku pomocou Manningovej rovnice, ktorá ovplyvňuje celkové množstvo povrchového odtoku (Schmidt, 1996). Drsnost' povrchu pôdy je počítaná upravenou Manningovou rovnicou nasledovným spôsobom (Michael, 1996):

$n=v_{q}^{-5 / 3} * q_{0}^{2 / 3} * S^{1 / 2}$

kde n -drsnost' povrchu podl'a Manning-Stricklera [s.m ${ }^{-1 / 3}$ ] (Michael, 1996),

$\mathrm{v}_{\mathrm{q}}$ - rýchlost' odtoku $\left[\mathrm{m} \cdot \mathrm{s}^{-1}\right]$,

$\mathrm{q}_{\mathrm{o}}$ - priemerná rýchlost' odtoku $\left.\left[\mathrm{m}^{2} \cdot \mathrm{s}^{-1}\right)\right]$,

$\mathrm{S}-$ sklon $\left[\mathrm{m} \cdot \mathrm{m}^{-1}\right]$.

\section{Empirický model USPED}

Model USPED (Unit Stream Power based Erosion/Deposition model) je empirický model, vytvorený na koncepte modelu USLE v 90. rokoch (Mitáš a Mitášová, 1998; Mitášová a kol., 1996), ktorý sa používa k modelovaniu potenciálnej miery erózie a depozície pôdy na pol'nohospodárskych plochách. Vstupnými parametrami do modelu sú DEM a hodnoty faktora R (erózna účinnost' dažd'a), K (erodovatel'nost' pôdy), C (ochranný vplyv vegetácie) a $\mathrm{P}$ (protierózne opatrenie).

\section{Opis povodia Svacenického jarku a batymetria dna}

Lokalizácia povodia Svacenického jarku je v oblasti Myjavskej pahorkatiny (obr. 1) v západnej časti Slovenskej republiky. Vd'aka prírodným a socio-ekonomickým zmenám podlieha oblast' Myjavskej pahorkatiny rýchlemu odtoku, čoho dôsledkom sú bahenné povodne. Výsledkom takmer 600-ročného antropogénneho pretvárania prirodzene zalesnenej krajiny Myjavskej pahorkatiny, ktorá bola tvorená najmä dubovými a bukovými lesmi, je súčasná krajina povodia, kde orná pôda zastupuje $66 \%$ plochy Myjavskej pahorkatiny. Zvyšok územia pokrývajú mozaiky lesov $(9 \%)$, trávnaté porasty $(9 \%)$, vodné plochy (7\%), záhrady (6\%), zástavba (2\%) a kroviny (1\%). Prevládajúci pôdny druh predstavujú luvizeme $(68 \%)$, nasleduje pararendzina $(28 \%)$ a najmenšie zastúpenie majú kambizeme $(3,7 \%)$. Vodný tok Svacenický jarok, predstavuje chrbtový tok územia a v spodnej časti sa vlieva do malej vodnej nádrže (poldra). Ked’že mesto Myjava bolo v minulosti postihnuté častými povodňami (Bučko a Mazurová, 1958; Stankoviansky, 1999; Stankoviansky, 2003; Dotterweich, a kol., 2013) bola zrealizovaná výstavba poldra Svacenického jarku ako súčast' protipovodňovej ochrany územia. Polder slúži predovšetkým na zníženie povodňových prietokov pravostranného prítoku toku Myjava - Svacenického jarku.

Hydrografický prieskum a zber údajov v Svacenickom poldri bol vykonaný pomocou zariadenia AUV (Autonomous Underwater Vehicle) prístrojom EcoMapper. Batymetria dna $\mathrm{v}$ poldri bola uskutočnená v spolupráci so Slovenskou akadémiou vied v rokoch 2015, 2016 a 2017. AUV Ecomapper je zariadenie, ktoré je schopné samostatne sa pohybovat' na povrchu a pod povrchom vodnej hladiny v híbke od 1 do 100 metrov. Pre analýzy $\mathrm{v}$ rámci tohto príspevku bolo zvolené obdobie od IX.2015 - XI.2016.

\section{Vstupné údaje}

Vstupnými údajmi pre oba modely boli zrážkové údaje v minútovom kroku počas obdobia IX.2015-X.2016 na 
meteorologickej stanici Myjava (v prípade modelu USPED boli stanovené mesačné a ročné úhrny zrážok). Modely boli validované na kontinuálnom rade nameraných zrážok. Obr. 2 zobrazuje vybrané zrážky počas zvoleného obdobia, tab. 1 uvádza charakteristiky jednotlivých zrážkových udalostí; dátum výskytu zrážkovej udalosti, trvanie zrážkovej udalosti (min), množstvo zrážkovej udalosti (mm) ako aj intenzitu zrážkovej udalosti $\left(\mathrm{mm} \cdot \mathrm{min}^{-1}\right)$. Ostatné zrážkové udalosti v tomto období neboli vhodné pre použitie v modelu EROSION3D (žiadna odozva modelu).

Ďalším vstupným parametrom boli pôdne charakteristiky, v prípade fyzikálne založeného EROSION-3D modelu ide o sedem pôdnych charakteristík (Michael a Schmidt, 1996). Ich podrobný prehl'ad s uvedením konkrétnych hodnôt uvádza tab. 2.

V prípade modelu USPED sumarizáciu vstupných charakteristík obsahuje tab. 3. Hodnoty C a P faktoru boli stanovené na základe literatúry (Janeček a kol., 2012), faktory $\mathrm{R}$ a $\mathrm{K}$ boli vypočítané na základe reálne meraných dát $\mathrm{v}$ povodí.

\section{Výsledky a diskusia}

Intenzívne erózne procesy v povodí Svacenického jarku sú spojené s miestami výrazne naklonených povrchov (nad $\left.10^{\circ}\right)$. Tieto plochy sa v území nachádzajú v blízkosti vodných tokov či eróznych rýh. V týchto miestach do-
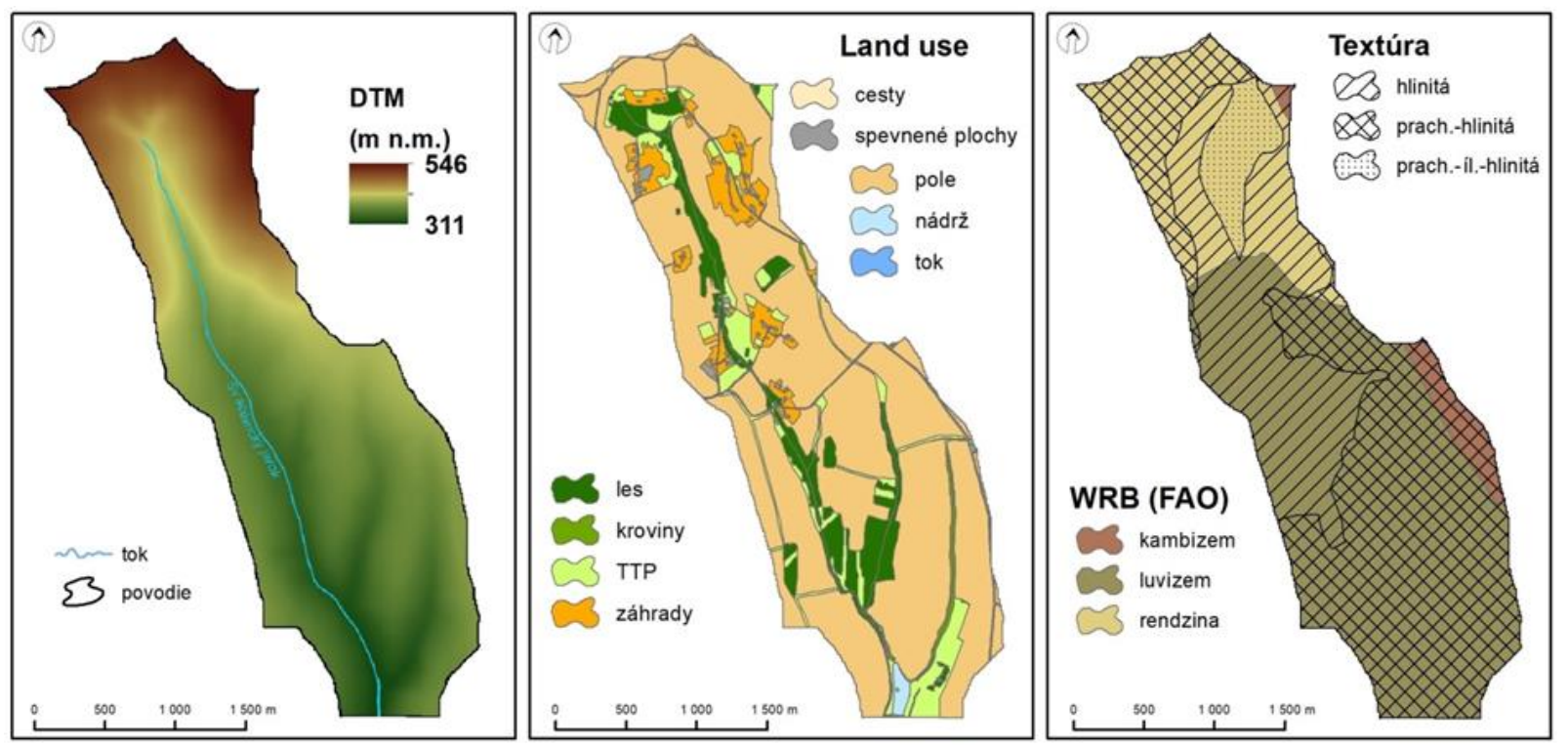

Obr. 1. Mapa lokalizácie povodia Svacenického jarku a DTM, mapa využitia územia a mapa pôdnych typov WRB (FAO) a druhov.

Fig. 1. The map of the Svacenicky jarok catchment, DEM, land use and soil conditions according to texture and WRB (FAO).

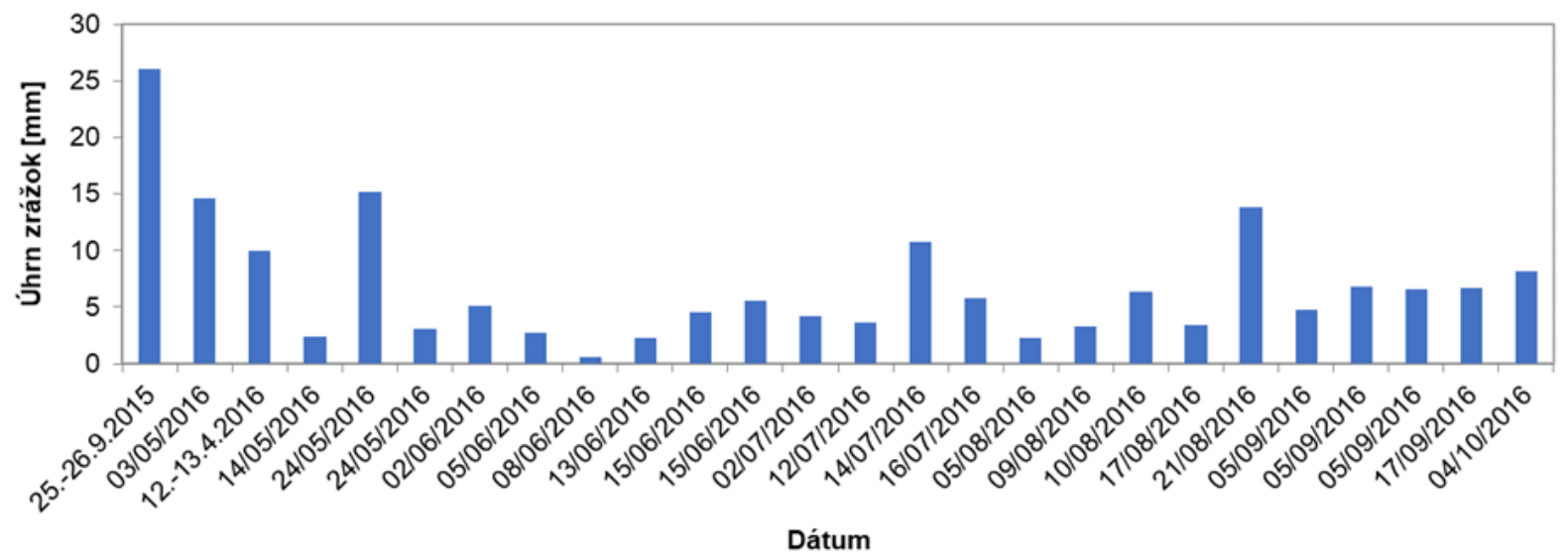

Obr. 2. Grafické zobrazenie vybraných zrážkových udalostí počas hodnoteného obdobia.

Fig. 2. Chosen rainfall events during investigated time period. 
Tabul'ka 1. Charakteristiky vybraných zrážkových udalostí počas hodnoteného obdobia

Table 1. Characteristics of chosen rainfall events during investigated time period

\begin{tabular}{|c|c|c|c|}
\hline $\begin{array}{c}\text { Dátum } \\
\text { zrážkovej udalosti }\end{array}$ & $\begin{array}{c}\text { Trvanie zrážkovej } \\
\text { udalosti } \\
\text { [min] }\end{array}$ & $\begin{array}{c}\text { Množstvo zrážkovej } \\
\text { udalosti } \\
{[\mathrm{mm}]}\end{array}$ & $\begin{array}{c}\text { Intenzita zrážkovej } \\
\text { udalosti } \\
{[\text { mm.min }} \\
\text { [mm }]\end{array}$ \\
\hline $25 .-26.09 .2015$ & 1041 & 26,11 & 0,03 \\
\hline 03.05 .2016 & 206 & 14,66 & 0,07 \\
\hline 12.-13.05.2016 & 260 & 9,92 & 0,04 \\
\hline 14.05 .2016 & 15 & 2.38 & 0,16 \\
\hline 24.05 .2016 & 161 & 15,22 & 0,09 \\
\hline 24.05 .2016 & 46 & 3,07 & 0,07 \\
\hline 02.06 .2016 & 64 & 5,15 & 0,08 \\
\hline 05.06 .2016 & 39 & 2,69 & 0,07 \\
\hline 08.06 .2016 & 1 & 0,57 & 0,57 \\
\hline 13.06 .2016 & 22 & 2,23 & 0,1 \\
\hline 15.06 .2016 & 67 & 4,5 & 0,07 \\
\hline 15.06 .2016 & 58 & 5,5 & 0,09 \\
\hline 02.07 .2016 & 8 & 4,18 & 0,52 \\
\hline 12.07 .2016 & 28 & 3,64 & 0,13 \\
\hline 14.07 .2016 & 241 & 10,71 & 0,04 \\
\hline 16.07 .2016 & 336 & 5,74 & 0,02 \\
\hline 31.07 .2016 & 122 & 2,2 & 0,02 \\
\hline 05.08 .2016 & 81 & 2,3 & 0,03 \\
\hline 09.08 .2016 & 48 & 3,32 & 0,07 \\
\hline 10.08 .2016 & 333 & 6,4 & 0,02 \\
\hline 17.08 .2016 & 50 & 3,38 & 0,07 \\
\hline 21.08 .2016 & 79 & 13,8 & 0,18 \\
\hline 05.09 .2016 & 141 & 4,71 & 0,03 \\
\hline 05.09 .2016 & 56 & 6,75 & 0,12 \\
\hline 17.09 .2016 & 31 & 6,66 & 0,22 \\
\hline 04.10 .2016 & 252 & 8,11 & 0,03 \\
\hline
\end{tabular}

Tabul'ka 2. Sumarizácia pôdnych vstupných parametrov pre fyzikálne založený model EROSION-3D (Michael, Schmidt, 1996)

Table 2. Summary of input soil parameters for physically based model EROSION-3D (Michael and Schmidt, 1996)

\begin{tabular}{|l|c|c|c|c|c|c|}
\hline \multirow{2}{*}{ Pôdne parametre } & \multicolumn{3}{|c|}{ Pšenica } & \multicolumn{3}{c|}{ Kukurica } \\
\cline { 2 - 7 } & Hlinitá pôda & $\begin{array}{c}\text { Prachovito- } \\
\text { hlinitá }\end{array}$ & $\begin{array}{c}\text { Prachovito- } \\
\text { ilovito-hlinitá }\end{array}$ & $\begin{array}{c}\text { Hlinitá } \\
\text { pôda }\end{array}$ & $\begin{array}{c}\text { Prachovito- } \\
\text { hlinitá }\end{array}$ & $\begin{array}{c}\text { Prachovito- } \\
\text { ilovito- } \\
\text { hlinitá }\end{array}$ \\
\hline $\begin{array}{l}\text { Objemová hmotnost' } \\
{\left[\mathrm{kg} . \mathrm{m}^{-3}\right]}\end{array}$ & $1497-1587$ & $1432-1493$ & $1479-1552$ & $\begin{array}{c}1341- \\
1491\end{array}$ & $1329-1479$ & $1328-1458$ \\
\hline $\begin{array}{l}\text { Počiatočná vlhkost' pôdy } \\
{[\%]}\end{array}$ & $30-45$ & $30-45$ & $30-45$ & $30-45$ & $30-45$ & $30-45$ \\
\hline $\begin{array}{l}\text { Obsah organickej hmoty } \\
{[\%]}\end{array}$ & $1,473-1,502$ & $\begin{array}{c}1,420- \\
1,480\end{array}$ & $1,490-1,557$ & $\begin{array}{c}1,350- \\
1,473\end{array}$ & $\begin{array}{c}1,650- \\
1,750\end{array}$ & $1,465-1,557$ \\
\hline $\begin{array}{l}\text { Erózna odolnost' } \\
{\left[\mathrm{N} \cdot \mathrm{m}^{-2}\right]}\end{array}$ & $0,0049-$ \\
0,0081 & $0,003-$ & 0,023 & $0,004-0,0053$ & $\begin{array}{c}0,0008- \\
0,0047\end{array}$ & $\begin{array}{c}0,001- \\
0,002\end{array}$ & $\begin{array}{c}0,0007- \\
0,0033\end{array}$ \\
\hline $\begin{array}{l}\text { Drsnost' } \\
{\left[\mathrm{s} . \mathrm{m}^{-1 / 3}\right]}\end{array}$ & $0,020-0,043$ & $\begin{array}{c}0,015- \\
0,023\end{array}$ & $0,013-0,023$ & $\begin{array}{c}0,015- \\
0,075\end{array}$ & $\begin{array}{c}0,015- \\
0,075\end{array}$ & $0,015-0,075$ \\
\hline $\begin{array}{l}\text { Pokrytie povrchu pôdy } \\
{[\%]}\end{array}$ & $0-100$ & $0-100$ & $0-100$ & $0-100$ & $0-100$ & $0-100$ \\
\hline $\begin{array}{l}\text { Opravný koeficient } \\
{[-]}\end{array}$ & $0,08-1$ & $0,08-1$ & $0,08-1$ & $0,08-1$ & $0,08-1$ & $0,08-1$ \\
\hline
\end{tabular}


chádza k depozícii erodovaného materiálu, ktorý sa hromadí na úpätí svahov. Všeobecne je však miera erózie v povodí mierna (do 5 t.ha ${ }^{-1}$ rok $^{-1}$ ). Z porovnania výsledkov modelovania pestovania úzko a širokoriadkových plodín jasne vyplýva, že širokoriadkové plodiny ako kukurica predstavujú vel'ké nebezpečie, ktoré môže viest' $\mathrm{k}$ intenzívnej erózii a degradácii pôdy v území. Model EROSION 3D predpokladá približne dvojnásobne väčšiu mieru erózie pri kukurici ako pri pšenici (obr. 3). U modelu USPED je rozdiel až 4-násobný (obr. 4).

Výsledné hodnoty objemu erodovaného materiálu sú sumarizované v tab. 4. Podl'a batymetrického prieskumu sa vo zvolenom období v nádrži usadilo asi $301,5 \mathrm{~m}^{3}$ sedimentov (pri uvažovanom zvodnení sedimentov 56,5\%). Výsledky z modelu EROSION-3D sa blížia k tejto referenčnej hodnote a je zrejmé, že reálna hodnota sa pohybuje medzi zvolenými scenármi pestovaných plodín, ktoré tak dobre simulujú reálnu situáciu v povodí. Výsledky z modelu USPED nadhodnocujú množstvo sedimentov, ako bolo predpokladané (u kukurici na siláž je rozdiel až $2365 \mathrm{~m}^{3}$ ).

Empirické modely ako USPED slúžia najmä pre stanovenie dlhodobej intenzity potenciálnej erózie či depozície a pre potreby priestorovej lokalizácie miest ohrozených vodnou eróziou, ako je vidiet' na obr. 4. Presnost' výpočtu reálneho objemu erodovaného materiálu je zat'ažená nepresnost'ou vlastných vstupných parametrov, ktoré len parametrizujú reálne prírodné podmienky (Wischmeier a Smith, 1978). K tomu taktiež prispieva možné nadhodnotenie vplyvu zrážkových úhrnov (aj napriek tomu, že výsledná hodnota $\mathrm{R}$ faktora 169,3 je relatívne nízka, pretože zvolené obdobie bolo zrážkovo podpriemerné), kde na rozdiel od epizódneho modelu EROSION-3D, ktorý berie v úvahu len vybrané erózne účinné dažde, empirické modely uvažujú vplyv celkových ročných a mesačných úhrnov. To všetko vedie k záveru, že pre potreby presného modelovania objemu erodovaného materiálu (čo je dôležité najmä pri výpočte

Tabul'ka 3. Sumarizácia vstupných parametrov pre empirický model USPED

Table 3. Summary of input parameters of model USPED

\begin{tabular}{|c|c|c|c|c|}
\hline Parametre & $\begin{array}{c}\mathbf{R} \\
{\left[\mathrm{MJ} \cdot \mathrm{mm} \cdot \mathrm{ha}^{-1} \cdot \mathbf{h}^{-1} \cdot \mathbf{y r}^{-1}\right]}\end{array}$ & $\begin{array}{c}\mathrm{K} \\
{\left[\text { t.ha.h.ha- } \mathrm{MJ}^{-1} \cdot \mathrm{mm}^{-1}\right]}\end{array}$ & $\begin{array}{c}\mathbf{C} \\
{[-]}\end{array}$ & $\begin{array}{l}\mathbf{P} \\
{[-]}\end{array}$ \\
\hline \multirow{2}{*}{ Hodnota } & \multirow{2}{*}{169,3} & \multirow{2}{*}{0,017} & 0,72 (kukurica) & \multirow{2}{*}{1} \\
\hline & & & 0,12 (pšenica) & \\
\hline
\end{tabular}

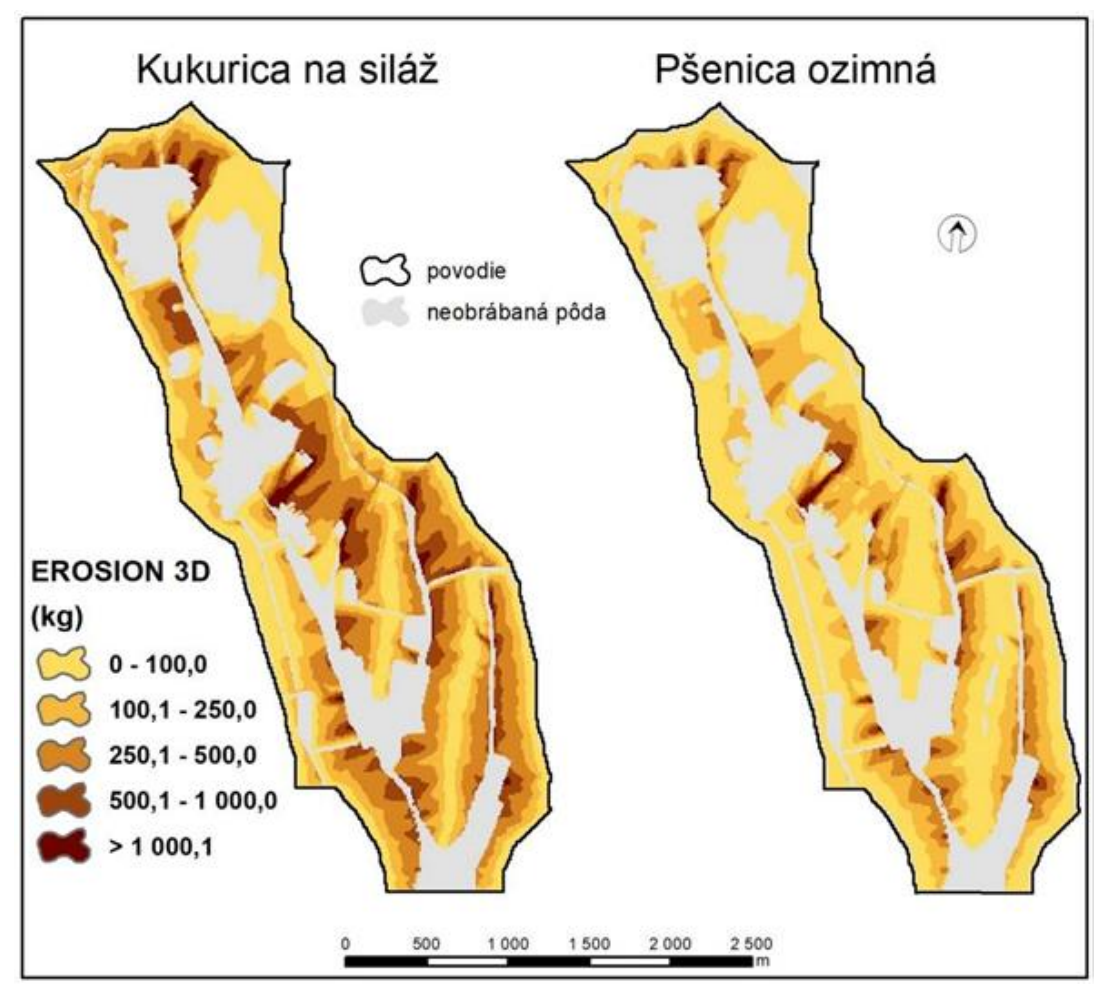

Obr. 3. Množstvo sedimentov pre kukuricu na siláž a pšenicu ozimnú (Erosion-3D model).

Fig.3. Sediment budget calculated for silage corn and winter wheat (EROSION-3D model). 
Tabul'ka 4. Porovnanie výstupov jednotlivých modelov a výsledkov získaných batymetriou dna Svacenického poldra

Table 4. Comparison between models' outputs and bathymetric measurement in the Svacenicky polder

\begin{tabular}{|l|c|c|c|}
\hline & EROSION- 3D & USPED & $\begin{array}{c}\text { MERANÉ } \\
\text { SEDIMENTY }\end{array}$ \\
\hline Modelované druhy plodín & \multicolumn{3}{|c|}{ Objem sedimentov $\left[\mathbf{m}^{3}\right]$} \\
\hline Pšenica ozimná & 270,0 & 712,9 & \multirow{2}{*}{301,5} \\
\hline Kukurica na siláž & 658,0 & 2666,8 & \\
\hline
\end{tabular}

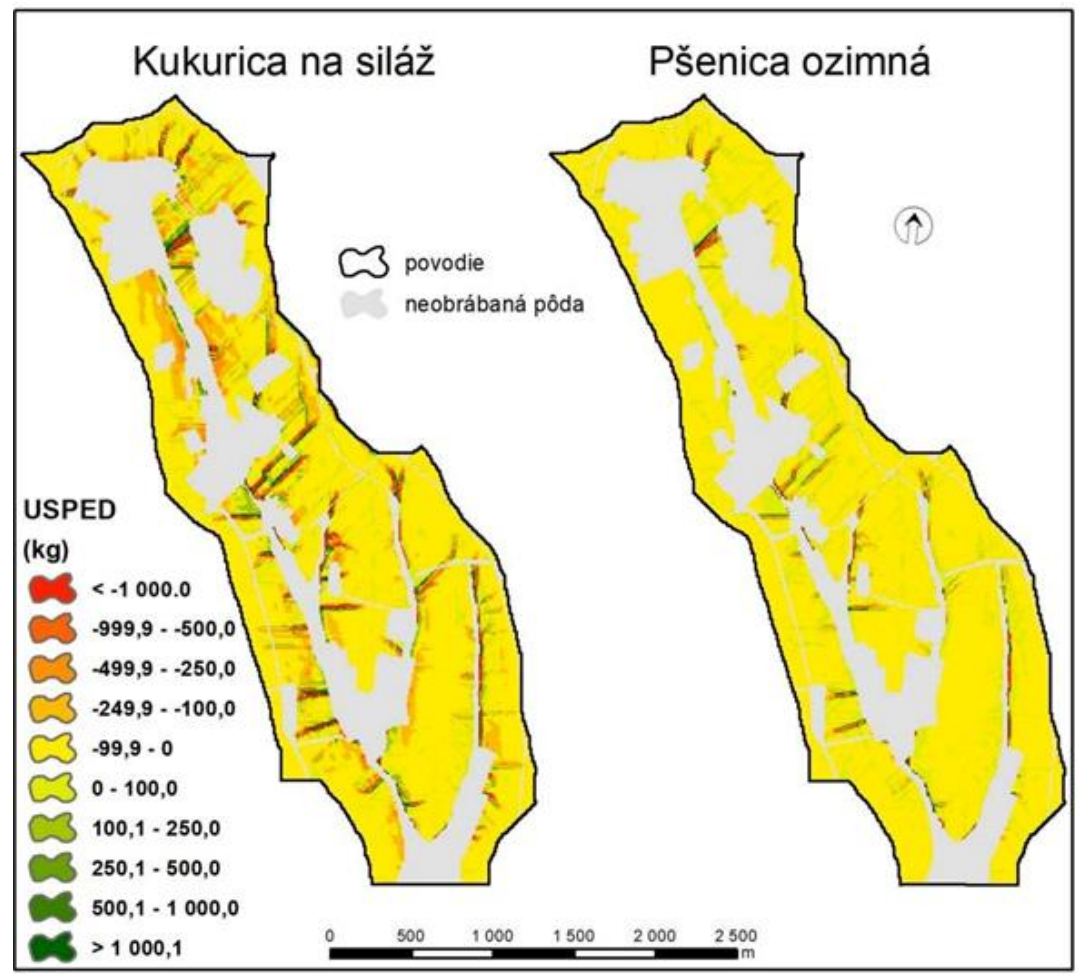

Obr. 4 Množstvo sedimentov pre kukuricu na siláž a pšenicu ozimnú (model USPED).

Fig. 4. Sediment budget calculated for silage corn and winter wheat (model USPED).

životnosti vodných nádrží), predstavuje model EROSION-3D omnoho vhodnejší prístup.

Podobnou problematikou sa zaoberal Kavka (2011), ktorý vo svojej práci validoval funkčnost' fyzikálne založeného simulačného modelu SMODERP. Validácia modelu bola uskutočnená na výsledkoch meraných na dažd’ovom simulátore, ako aj na dátach nameraných na experimentálnych eróznych plochách. Podl'a Hasholta (1998) neexistuje univerzálny spôsob validácie modelov. Quinton (1994) vo svojej práci rozoberá validáciu epizódneho a fyzikálne založeného erózneho modelu EUROSEM a považuje za dôležité vykonávat' validáciu modelu predovšetkým v súvislosti s hlavným účelom, pre ktorý bol model navrhnutý. Tak isto podrobne popisuje charakteristiky validácie fyzikálne založených modelov; a to od základných krokov, ktoré je potrebné vy- konat' pred samotnou validáciou až po konečné hodnotenie úspešnosti validácie modelov. O jednotlivých aspektoch validácie modelov vypovedá práca od autorov Refsgaarda a Knudsena (1996), kde sú opísané teoretické princípy validácie troch modelov; fyzikálne založeného hydrologického modelu MIKE SHE, klimatického modelu WatBal a koncepčného zrážkovo-odtokového modelu NAM.

\section{Záver}

Ciel'om príspevku bolo určenie množstva sedimentov fyzikálne založeným modelom EROSION-3D a empirickým modelom USPED a porovnanie modelových výsledkov s nameraným množstvom sedimentov v povodí Svacenického jarku. Výpočty boli uskutočnené pre dve 
plodiny pestované v analyzovanom území; pšenicu ozimnú a kukuricu na siláž. $Z$ dosiahnutých modelových výstupov možno konštatovat', že empirický model USPED značne nadhodnocuje množstvo sedimentov v porovnaní s fyzikálne založeným modelom EROSION-3D. Na druhej strane sa model USPED preukázal ako vhodný nástroj pre lokalizáciu miest, ktoré sú náchylné na vodnú eróziu. Medzi jeho hlavnú nevýhodu patrí najmä nadhodnotenie vplyvu zrážkových úhrnov (vplyv celkových ročných a mesačných úhrnov), pričom EROSION-3D model pracuje iba s tzv. erózne účinnými zrážkami. V zmysle modelovaných plodín sa bližšie $\mathrm{k}$ nameraným dátam približuje pšenica ozimná a to $\mathrm{v}$ prípade fyzikálne založeného EROSION-3D modelu ako aj empirického modelu USPED. Na základe uvedeného možno zhrnút', že fyzikálne založený EROSION-3D model preukázal vyššiu presnost' modelových výstupov vo vzt’ahu k meraných dátam ako empirický model USPED.

\section{Pod'akovanie}

Príspevok vznikol vd'aka podpore APVV 15-0497, za čo sú autori práce vd'ační.

\section{Literatúra}

Bhattarai, R., Dutta, D. (2007): Estimation of Soil Erosion and Sediment Yield Using GIS at Catchment Scale. Water Resources Management, 21, 1635-1647.

Boix-Fayos, C., De Vente, J., Martínez-Mena, M., Barbéra, G.G., Castillo, V. (2008): The impact of land use change and check-dams on catchment sediment yield. Hydrological Processes, 22, 4922-4935.

Bučko, Š., Mazurová, V. (1958): Výmol'ová erózia na Slovensku. Zborník: Vodná erózia na Slovensku, 68-101. Bratislava, SAV.

Bussi, G., Rodriguez-LloveraS, X., Francés, F., Benito, G., Sánchez-Moya, Y., Sopena, A. (2013): Sediment yield model implementation based on check dam infill stratigraphy in a semiarid Mediterranean catchment. Hydrology and Earth System Scien, 17, 3339-3354.

Dotterweich, M., Stankoviansky, M., Minár, J., Koco, Š., Papčo, P. (2013): Human induced soil erosion and gully system development in the Late Holocene and future perspectives on landscape evolution: The Myjava Hill Land, Slovakia. Geomorphology, 201, 227-245.

Erskine, W. D., Mahmoudzadeh, A., Myers, C. (2002): Land use effects on sediment yields and soil loss rates in small basins of Triassic sandstone near Sydney, NSW, Australia. Catena, 49, 271-287.

García-Ruiz, J. M., Beguería, S., Nadal-Romero, E., González-Hidalgo, J. C., Lana-Renault, N., Sanjuán, Y. (2015): A meta-analysis of soil erosion rates across the world. Geomorphology, 239, 160-173.

Hasholt, B. (1998): Assessment of erosion and some implications for model validation. Modelling Soil Erosion, Sediment Transport and Closely Related Hydrological Processes (Proceedings of a symposium held at Vienna, July 1998). IAHS Publ., 249-260.
Hlavčová, K., Kohnová, S., Velísková, Y., Studvová, Z., Sočuvka, V., Ivan, P. (2018): Comparison of two concepts for assessment of sediment transport in small agricultural catchments. Journal of Hydrology and Hydromechanics, 66, 4, 404-415.

Janeček, M. a kol. (2012): Ochrana zemědělské půdy před erozí. ČZU, Prague, 113.

Michael, A, Schmidt, J., Schmidt, W. (1996): Band II: Parameterkatalog Sachsen Anwendung. In EROSION 2D/3D Ein Computermodell zur Simulation der Bodenerosion durch Wasser; Sächsische Landesanstalt für Landwirtschaft, Sächsisches Landesamt für Umwelt und Geologie: Dresden, Freiberg, Germany, 121.

Midriak, R. (1993): Únosnost' a racionálne využívanie územia vysokých pohorí Slovenska. Bratislava, SZOPK.

Mitáš, L., Mitášová, H. (1998): Distributed soil erosion simulation for effective erosion prevention. Water Resources Research, 34, 3, 505-516.

Mitášová, H., Hofierka, J., Zlocha, M., Iverson, L. R. (1996): Modelling topographic potential for erosion and deposition using GIS. International Journal of GIS, 10, 5, 629-641.

Montgomery, D. R. (2007): Soil erosion and agricultural sustainability. Proceedings of the National Academy of Sciences of the United States of America, 104, 13268-13272.

Quinton, J. N. (1994): The validation of physically-based erosion models, with particular reference to EUROSEM. In: Rickson, R. J. (eds.): Conserving Soil Resources: European Perspectives, 300-313. CAB International, Wallingford, Oxfordshire, UK.

Rawat, P. K., Tiwari, P. C., Pant, C. C., Sharama, A. K., Pant, P. D. (2011): Modelling of stream run-off and sediment output for erosion hazard assessment in Lesser Himalaya: need for sustainable land use plan using remote sensing and GIS: a case study. Natural Hazards, 59, 1277-1297.

Refsgaard, J.C., Knudsen, J. (1996): Operational Validation and Intercomparison of Different Types of Hydrological Models. Water Resources Research, 32, 2189-2202.

Schmidt, J. (1996): Entwicklung und Anwendung eines Physikalisch Begründeten Simulationsmodells für die Erosion Geneigter Landwirtschaftlicher Nutzflächen; Selbstverlag des Instituts für Geographische Wissenschaften: Berlin, Germany, 148.

Stankoviansky, M. (1999): Geomorphic response of agricultural landscape to land use changes associated with introduction of large-scale farming in Slovakia. In: Jambor, P., et al. [eds.]: Soil conservation in largescale land use, 49-58. Bratislava, ESSC, SSCRI.

Stankoviansky, M. (2003): Geomorfologická odozva environmetálnych zmien na území Myjavskej pahorkatiny. Bratislava, Comenius University, 157.

Terranova, O., Antronico, L., Coscarelli, R., Iaquinta, P. (2009): Soil erosion risk scenarios in the Mediterranean environment using RUSLE and GIS: An application model for Calabria (Southern Italy). Geomorphology, 112, 228-245.

Wishmeier, W. H., Smith, D. D. (1978): Predicting Rainfall Erosion Losses - A Guide to Conservation Planning. Washington, USDA, 67. 


\section{MODELLING OF SEDIMENT AMOUNTS BY A PHYSICALLY BASED EROSION-3D MODEL AND EMPIRICAL MODEL USPED IN THE SVACENICKY CREEK CATCHMENT}

The study presents the determination of sediment amounts using two different kinds of methods; physically based models and empirical models in the agricultural catchment. The main goal of the article includes the quantification of sediment amounts using physically based model and empirical model and confrontation the modelled results with the real measured data. The measured data were obtained by the bathymetry measurement in the Svacenicky Jarok polder. The polder bathymetry measurement was performed using Autonomous Underwater Vehicles (EcoMapper) which represents a device able to move on the surface level in water with depth more than one meter. The hydrographical survey and data mapping of the Svacenický polder were performed by Slovak Academy of Sciences in the year 2015 and 2016.

The calculations were targeted at the 27 rainfall events which have been determined as the erosion effective during 2015-2016 and for two land cover types; silage corn and winter wheat. The selected crops reflect the real conditions in the catchment. One minute rainfall data were measured at the Myjava rain-gauge station during chosen period time.

The study area is localized in the middle of the Myjava Hill Land situated in the western part of Slovakia. The area is strongly affected by quick runoff response and related muddy floods. It is thanks to $~ 600$-year anthropogenic transformation of the naturally forested landscape, which was predominantly formed by oak and beech forests. Nowadays more than half of the territory is covered by arable land (66\% of area), other parts of area consist of forests (9\%), grassland (9\%), water bodies $(7 \%)$, gardens $(6 \%)$ and shrubbery $(1 \%)$.

The results present differences between physically based EROSION-3D model and empirical model USPED and crop types selected. In general, erosion processes are moderate in the catchment (up to 5 tons per hectare/year). Considering the different types of crops, it is obvious that the effect of vegetation on runoff and sediment yields plays an important role in preventing runoff-erosion processes. According the results, it can be concluded that silage corn represents a major hazard causing the intense erosion and soil degradation in the area. The most intensive erosion processes were calculated for the silage corn using empirical model USPED. The results from the model USPED overestimated the amount of sediments in comparison with physically based EROSION-3D model. Empirical model USPED is more suitable for the spatial distribution of places endangered by water erosion.

Based on the polder bathymetry measurement, there was deposited about $301.5 \mathrm{~m}^{3}$ amount of sediments. The results from the Erosion-3D model are closer to this value and it is clear that the measured value fluctuates between crops selected. Both models are suitable for evaluating the effects of changing management practices on the sediments volume quantification. However, the empirical model USPED overestimated the sediment volume in the catchment in comparison with EROSION3D model and that's why physically based approach represents more relevant approach for the assessing runoff-erosion processes.

\author{
Mgr. David Honek \\ Geografický ústav, Př́rodovědecká fakulta, \\ Masarykova Univerzita, \\ Kotlářská 2, 611 37, Brno \\ Výzkumný ústav vodohospodářský T.G.M., \\ Podbabská 2582/30, 160 00, Praha 6 \\ Tel.: $\quad$ +420541126317 \\ E-mail: ston.david@windowslive.com
}

Ing. Zuzana Németová

prof. Ing. Silvia Kohnová, PhD.

Katedra vodného hospodárstva krajiny, Stavebná fakulta, Slovenská technická univerzita v Bratislave

Radlinského 11, 81005 Bratislava

Tel.: $\quad$ +421259274623

Fax: $\quad$ +421252967027

E-mail: zuzana.nemetova@stuba.sk silvia.kohnova@stuba.sk 